\title{
SOCIAL MEDIA USED BY LOCAL GOVERNMENTS OF THE LODZ VOIVODESHIP
}

\author{
Mariusz WOŹNIAKOWSKI \\ University of Lodz, Faculty of Management; mariusz.wozniakowski@uni.lodz.pl, \\ ORCID: 0000-0001-6423-5309
}

\begin{abstract}
Purpose: The purpose of the article is to present the assumptions of social media and their values in the communication of local government units on the example of cities in the Lodz region.
\end{abstract}

Design/methodology/approach: The conducted study consisted in analyzing the content of official websites belonging to local governments of individual cities of the Lodz voivodship to see how information about social networking sites used (plug-in location) and the profiles themselves in these media are communicated in order to check what and how is published. The survey was carried out in October 2019.

Findings: The study showed that out of the 44 cities analyzed in the Łódź Voivodeship 37 use at least one of the social networking sites. Most often it is Facebook - 36 cities have their profile, then YouTube - 19, Instagram -7 and Twitter - 6. 9 cities have 3 official profiles on different websites at the same time, and another 13 cities -2 each. For 7 cities, no profiles were found on social networking sites.

Research limitations/implications: The study did not include less popular social networking sites (e.g. TikTok, GoldenLine, Pinterest). The goals of communication activities by the promotion offices of individual cities are unknown. This can be part of further research through in-depth interviews with people responsible for promoting cities. Possible extension of research to cities of other provinces.

Practical implications: Based on the author's audit of the communication activity of the cities of the region on social networking sites, this article suggests that the use of social media is an appropriate tactic in promoting cities due to the participative, interactive, open and transparent nature of social media.

Originality/value: The publication presents the results of research carried out on the basis of the author's audit of the activity of the cities of the Lodz voivodship in the social media.

Keywords: social media, city marketing, city promotion, marketing communication.

Category of the paper: Research paper. 


\section{Introduction}

Constantly improved ICT (Information and Communication Technologies) infrastructure and the increasingly widespread use of technology have changed the way of modern interpersonal and, consequently, commercial communication. Already in 2013, YouTube and Facebook reached over one billion active users ("Number of active users at Facebook over the years", 2013; "YouTube hits a billion monthly", 2013). These and other social platforms (like Instagram, Twitter) have become popular in the everyday lives of citizens as well as cities (as local government units) in dealing with their residents online. Developed infrastructure in the field of ICT, as well as high penetration of the Internet in society, are prerequisites that guarantee that a large number of citizens can use social media and other communication channels on the Internet. Both of these factors can be found in the concept of "Informational Word Cities" (Stock, 2011; Mainka, Khveshchanka, and Stock, 2011), i.e. prototype cities of the knowledge society (like Singapore, New York or Hong Kong). Information cities consist of two spaces: space of places and space of flow. The space of places (i.e. of buildings, streets) is dominated by the space of flows (e.g. of money, power, information). Such cities are metropolises of the 21st century, which are a continuation of the concept of Manuel Castells's "Information cities" (Castells, 1989). 'World City' is defined by the degree of 'cityness' (Friedmann, 1995; Taylor, 2004; Sassen, 2001), where a large population does not necessarily constitute an information city. However, ICT infrastructure should be developed so that cities meet the needs of the space typical for an information city. On this occasion, there are also other terms related to the development of information and communication technologies in relation to cities, such as digital city (Yigitcanlar, and Han, 2010), smart city (Shapiro, 2006; Hollands, 2008), knowledge city (Ergazakis, Metaxiotis, and Psarras, 2004) and creative city (Landry, 2005; Florida, 2005).

In view of the above, the use by local government of modern forms of communication with its residents may play an important role in building social cohesion, which is, among others (in the understanding of the Council of Europe) the possibility for society to provide a relatively high quality of life and reduce the gap between standards. A cohesive society is a community of free and supportive people. The use of social media can be the stimulus for creating this cohesion. Skilful maintenance of profiles on such websites can contribute to the creation of a specific community of residents. In addition, it is an opportunity to inform residents noninvasively about the activities of local authorities, and thus a valuable source of information and another element to build an information society (Woźniakowski, 2015). Therefore, the purpose of the article is to present the assumptions of social media and their values in the communication of local government units on the example of cities in the Lodz region. 


\section{Social media and their value in communications}

A social website can be defined as a website directed at a specific social group or people with similar interests. These websites allow quite large interference of their users in their content and character (Rzepecki, and Hankus-Matuszek, 2009). What is the strength of social media is the fact that the fans visiting the profiles are not fully aware of the fact that behind the pleasing graphics and expressive texts under which they press the "Like" button, there stands an action plan, carefully arranged and thought out to the smallest detail, that assumes the opportunities, threats and potential benefits of every message, i.e. a network of efficiently selected facts and conclusions (Woźniakowski, 2015).

Looking through the prism of marketing, the best image message is one that will be regarded by the recipients as useful and valuable information, and not advertising (Lebkowski, 2009). The skilful use of social networking sites in marketing communications can result in the fact that by sending messages, an organization - a city - can build lasting relationships with recipients - residents (or other stakeholders, e.g. tourists, investors) that will not end with the conducted campaign (Rak, 2011). This means that a properly created, credible message will be received positively by the environment and will be further reproduced by the recipients. In addition, informal communication between recipients turns out to be much more effective than conducting standard promotional activities (Brunk, 2010).

It should be noted that the existence of own profiles in social media can be communicated via own website and some of the tools (such as blogs) can be included in the structure of the website. In addition to promoting own website (including positioning), the use of social media by local governments is desirable due to the following facts (Podlaski, 2011; Żak, 2015):

- they play a big role in the everyday life of recipients. Many of them use social networking sites every day, they are part of their lives;

- they strengthen the image, credibility and trust through longer participation in the life of social networks and continuous contact with users;

- they provide feedback from users. Social media enable establishing relationships with the public office's stakeholders at a completely new level. Users can make direct contact and get extremely valuable information on, for example, the office's activities, opinions on current events in the city, commune, etc.;

- they have a wide range of access to the public, and thanks to various activities, various communication goals addressed to specific groups of recipients can be achieved;

- owing to website users, meta information (information containing other data) is created;

- they contain the so-called social component and are viral. 


\section{Social media used by the cities of the Lodz region}

The conducted study consisted in analyzing the content of official websites belonging to local governments of individual cities of the Lodz voivodship (Table 1) to see how information about social networking sites used (plug-in location) and the profiles themselves in these media are communicated in order to check what and how is published. In the absence of a link on the website to the most popular social networking site - Facebook, this profile was searched by an internal search engine on the portal itself. The survey was carried out in October 2019.

\section{Table 1.}

The use of selected social networking sites by the municipalities of the Lodz voivodshipas of September 2019 (the value in brackets means no profile plug-in on the websitethe profile was found through the social network search engine)

\begin{tabular}{|c|c|c|c|c|c|c|c|c|c|}
\hline \multirow[b]{3}{*}{ Item } & \multirow[b]{3}{*}{ City } & \multicolumn{8}{|c|}{ Name of the social network } \\
\hline & & \multicolumn{2}{|c|}{ Facebook } & \multicolumn{2}{|c|}{ YouTube } & \multicolumn{2}{|c|}{ Instagram } & \multicolumn{2}{|c|}{ Twitter } \\
\hline & & 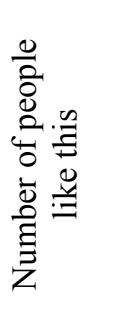 & 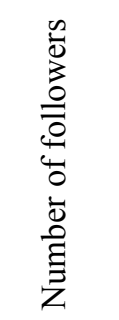 & 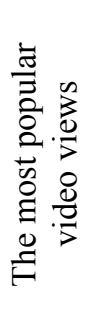 & 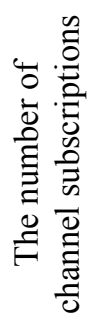 & 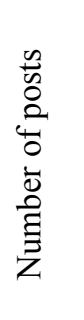 & 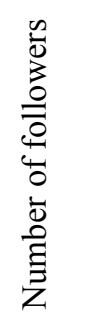 & 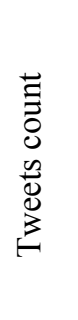 & 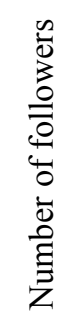 \\
\hline 1 & Aleksandrów Łódzki & 9202 & 9450 & 126984 & 671 & - & - & - & - \\
\hline 2 & Bełchatów & (13954) & (14333) & 255605 & 644 & - & - & - & - \\
\hline 3 & Biała Rawska & - & - & - & - & - & - & - & - \\
\hline 4 & Błaszki & - & - & - & - & - & - & - & - \\
\hline 5 & Brzeziny & 3260 & 3405 & - & - & - & - & - & - \\
\hline 6 & Drzewica & 2072 & 2136 & - & - & - & - & - & - \\
\hline 7 & Działoszyn & - & - & - & - & - & - & - & - \\
\hline 8 & Głowno & 4378 & 4524 & - & - & - & - & - & - \\
\hline 9 & Kamieńsk & 32 & 32 & - & - & - & - & - & - \\
\hline 10 & Koluszki & 4480 & 4631 & - & - & - & - & 22 & 58 \\
\hline 11 & Konstantynów Łódzki & 8700 & 8879 & 1037 & 24 & 150 & 900 & - & - \\
\hline 12 & Krośniewice & $(975)$ & $(995)$ & - & - & - & - & - & - \\
\hline 13 & Kutno & 12462 & 12636 & - & - & - & - & - & - \\
\hline 14 & Łask & 2626 & 2700 & - & - & - & - & - & - \\
\hline 15 & Łęczyca & 2870 & 2922 & 10016 & 65 & - & - & - & - \\
\hline 16 & Łowicz & 10851 & 10983 & - & - & - & - & - & - \\
\hline 17 & Łódź & 341049 & 344261 & - & - & 3596 & 62800 & 4228 & 5945 \\
\hline 18 & Opoczno & 3811 & 3902 & 10833 & 451 & - & - & - & - \\
\hline 19 & Ozorków & - & - & 9288 & 545 & - & - & - & - \\
\hline 20 & Pabianice & 2459 & 2554 & - & - & - & - & - & - \\
\hline 21 & Pajęczno & - & - & - & - & - & - & - & - \\
\hline 22 & Piotrków Trybunalski & 8154 & 8386 & - & - & - & - & - & - \\
\hline 23 & Poddębice & 553 & 571 & - & - & - & - & - & - \\
\hline 24 & Przedbórz & - & - & - & - & - & - & - & - \\
\hline 25 & Radomsko & 4580 & 4729 & 18066 & 138 & - & - & 2029 & 634 \\
\hline 26 & Rawa Mazowiecka & 3328 & 3469 & - & - & - & - & - & - \\
\hline 27 & Rzgów & - & - & - & - & - & - & - & - \\
\hline 28 & Sieradz & 4399 & 4493 & - & - & 62 & 481 & - & - \\
\hline 29 & Skierniewice & 15420 & 15670 & 6218 & 287 & 505 & 2444 & - & - \\
\hline 30 & Stryków & 1824 & 1914 & 7048 & 255 & - & - & - & - \\
\hline 31 & Sulejów & 2354 & 2481 & - & - & - & - & - & - \\
\hline
\end{tabular}


Cont. table 1.

\begin{tabular}{|l|l|r|r|r|r|r|r|r|r|}
\hline 32 & Szadek & 218 & 229 & - & - & - & - & - & - \\
\hline 33 & Tomaszów Mazowiecki & 11074 & 11277 & 51174 & 387 & - & - & 137 & 170 \\
\hline 34 & Tuszyn & - & - & - & - & - & - & - & - \\
\hline 35 & Uniejów & 5527 & 5672 & 761 & 26 & - & - & - & - \\
\hline 36 & Warta & 1673 & 1689 & 1589 & 21 & - & - & 1 & 1 \\
\hline 37 & Wieluń & 11107 & 11189 & 38157 & 136 & 73 & 2658 & - & - \\
\hline 38 & Wieruszów & 3388 & 3483 & 2892 & 47 & 72 & 266 & - & - \\
\hline 39 & Wolbórz & 1675 & 1717 & 8588 & 20 & - & - & - & - \\
\hline 40 & Zduńska Wola & 5740 & 5830 & 331 & 80 & - & - & 359 & 136 \\
\hline 41 & Zelów & 1778 & 1842 & 2083 & 65 & - & - & - & - \\
\hline 42 & Zgierz & 11134 & 11535 & 17564 & 238 & - & - & - & - \\
\hline 43 & Złoczew & 4324 & 4372 & - & - & 259 & 500 & - & - \\
\hline 44 & Żychlin & 3672 & 3652 & 3764 & 46 & - & - & - & - \\
\hline
\end{tabular}

Source: own research.

The study showed that out of the 44 cities analyzed in the Eódź Voivodeship 37 use at least one of the social networking sites listed above. Most often it is Facebook - 36 cities have their profile, then YouTube -19 , Instagram -7 and Twitter -6.9 cities have 3 official profiles on different websites at the same time, and another 13 cities -2 each. Table 1 shows which cities have their profiles on individual websites along with the number of fans and/or publications and/or views. For 7 cities, no profiles were found on social networking sites.

The profiles on Facebook are generally up-to-date, and the numbers of fans indicate that this tool has a big potential in office-resident communication. In many cases, subsequent posts are added daily, or even several times a day. They usually relate to current events in the city and contain numerous photos or videos. All published posts can be grouped according to the following categories:

- For residents (health/social assistance, temporary traffic difficulties, civic budget, coverage of events, education).

- Free time (cultural and sporting events, openings of new gastronomic premises, presentation of places, "behind the scenes" of municipal institutions, eg showing the work of a tram depot, contests, memes).

- Tourism (tourist attractions, history of places - photos and graphics "sometime and now", festivals).

- Investments/renovations/business (public and commercial, new jobs, fairs and conferences).

In the case of the second analyzed site - YouTube, the number of subscribers of individual channels/profiles is definitely smaller than on Facebook. However, this is not a cause for concern for the cities behind them, because here the number of views of individual films is more important.

The YouTube channel is sometimes treated as a kind of Internet television (channels: Bełchatów TV, TV Ozorków, in the second case there is no information as to whether it is the official channel of the city) or just a regional information service ("Zgierska przestrzeń"). In some cases, the channel broadcasts only the deliberations of the city council or city commissions (Zelów, Wieruszów, Stryków). 
The biggest problem with YouTube's identified channels is the randomness of published videos and the low number of videos as a consequence of the lack of new publications. For example, the most popular movie on the Bełchatów channel is de facto external material Discovery Science "Przemysłowy zawrót głowy. Węgiel" about the functioning of the lignite mine located in the commune. However, a large time interval from the last publication occurs for the following channels: Konstantynów Łódzki (last video posted in December 2017), Łęczyca (June 2018), Radomsk (June 2019), Uniejów (November 2018), Wolbórz (December 2014, a total of 4 films from the same year), Zduńska Wola (November 2017), Żychlin (July 2019, a total of 7 films since 2011).

In the third analyzed social network - Instagram, on 2 identified profiles - Wieruszów and Konstantynów Łódzki, activity ceased in August 2018 and February 2019, respectively. In the case of the profiles of Sieradz, Skierniewice, Wielun and Złoczew, new posts appear quite rarely (at intervals of several days or even several weeks). In the case of Instagram, the problem for cities is to provide relevant content. The specificity of the website is visual content, mainly photos, hence the publications should have some sort of artistic value, or at least professional photo sessions. Consequently, the lack of a clearly defined purpose of having an Instagram profile is evident. In the case of Sieradz, posts are extremely varied and match Instagram's character. In the remaining 3 cases (Skierniewice, Wieluń, Złoczew), the content is dominated by graphics related to cultural and entertainment events as well as landscapes. The profile of Łódź stands out against this background. It is the only one actively managed, and the published posts (all bearing, among others, the hashtag \#kochamlodz) fit into the nature of the website. The vast majority of posts refer to the presentation of various places in the city, often in an unusual way, thus expressing quite symbolically the "spirit" of the city, which may encourage visitors to visit the places presented by both residents and tourists.

In the case of the last analyzed site - Twitter, 5 identified city profiles are sporadically updated (Zduńska Wola, Tomaszów Mazowiecki) or any activity (Koluszki, Radomsko, Warta) has been discontinued. Against this background, the only exception is the profile of Łódź, which is updated on a regular basis, sometimes several tweets are added per day. Mostly, they relate to current events in the city, although there are also ones that encourage activity (e.g. searching for more and more detailed messages) on other websites, mainly on Facebook. As for the idea, the appearing entries fit into the nature of the website, which was created with the intention of publishing short messages. 


\section{The most common mistakes in social media activities}

Local governments also do not avoid errors in communication through social networking sites. First of all, the problem is the placement of plugins for social networking sites in the structure of the page. They should be in a visible place, preferably at the top of the page, or in the bottom menu (if it exists) or footer. However, it happens that they are in a hardly visible place in the structure of the site (Bełchatów, Rawa Mazowiecka), or plugs for different profiles are in different places of the site (Opoczno) or they are simply not there (and the profile exists - Bełchatów, Krośniewice). Additionally, clicking the plug-in should result in opening the given profile in a new browser tab, and not in replacing the currently displayed content (Aleksandrów Łódzki, Łódź, Sieradz).

Another problem is keeping inactive profiles. It happens that despite placing the plugin for the social website in a visible place of the page, after redirecting to the profile, you will see outdated information or the lack of any. This is the case with, for example, Kamieńsk's profile on Facebook. On June 11, 2019, the profile photo and background photo were updated, followed by June 15, the first post, the second and last on September 24. In turn, when you click the YouTube plug-in, the message "page unavailable" appears on the Piotrków Trybunalski website. Similar problems arise with the Facebook profiles of the following cities: Poddębice, Szadek; Twitter: Koluszek, Skierniewice, Tomaszów Mazowiecki, Warta (only one entry at all); Instagram: Konstantynów Łódzki. In the absence of current content, there is no point in having a profile on a social networking site as it denies the basic idea of their functioning, and for the viewer, it may give the impression that in a given city nothing interesting and worth showing happens. In the case of Aleksandrów Łódzki and Zgierz, there are plugins for Google+ profiles on the pages, however, the service itself from April 2019 no longer provides services on individual user accounts or brand

There is a lack of consistency in messaging through social networking sites. By adopting a coherent communication strategy using profiles on individual websites, you can achieve synergy effects, conduct cross-activities, e.g. by encouraging Facebook users to track their Instagram account, because it will announce a contest for residents. Such a lack of consistency is visible, for example, in the communication of the city of Uniejów, where the information "Thermal Spa" (Facebook, website, press materials) often appears, while the YouTube channel signed "umuniejów" lacks a profile photo (usually it is the city's coat of arms or another characteristic symbol for a given city), the subject of the films is quite random and is published irregularly.

Inappropriate use of humour in published posts. Due to the less formal nature of communication through social media, memes or humorous entries referring to current events in the city are a frequent element of posts even of public institutions. However, in this case, some common sense should be shown, because some entries may meet with a lack of understanding 
or even negative perception by the residents. For example, on the Facebook profile of $€$ ódź on October 2, a photo report from the reconstruction of Nawrot Street appeared with the following entry: "The oldest residents of Łódź do not remember the date when the Nawrot renovation commenced, but the youngest will definitely see its end ...", which was supposed to be a funny reference to the expected completion of a troublesome renovation, whose original date has been postponed several times (in total, nearly a year's delay). Over 200 comments appeared under the post, mostly with negative overtones, that for residents it is not funny, and the way the investment is carried out shows the incompetence of officials and contractors.

The last mistake (although all the above certainly do not exhaust the topic) is too many profiles maintained in a situation where there is no clear communication strategy using social media. In this case, one can stick to the principle that less is more. For example, on the Opoczno website, 3 plugins for 3 different city profiles on Facebook can be found. The first is "Opoczno stolicą oberka", the second is associated with the Ceramic Tile Festival and the last is the proper commune profile. It seems that all three of them could be made into one profile, the more so that in the case of the first two profiles publications are quite sporadic.

\section{Summary}

Interpersonal communication is constantly evolving, and so is the communication between the office and the resident (investor, tourist, etc.). Various types of innovations introduced in this field may temporarily improve the communication process or even revolutionize it, as was the case with the Internet (Woźniakowski, 2015).

Summing up the activities of the cities of the Lodz region in social networking sites, it should be said that only the first steps were made. Unfortunately, in some cases, it was even a step backwards due to errors made, mainly the lack of new posts or leaving profiles inactive. The capital of the region certainly stands out from all the analyzed cities; its activities can be a reference point for other cities. Of course, this should not be a duplication of the city of Łódź activities, but rather looking for one's own path. For social media communication activities to be effective, a well-thought-out action plan should be set up, consistent for all channels. Without this, in many cases, there will still be a sense of chaos and randomness of the content posted. In addition, local governments that are in no way present on the Internet (except for a website that is something natural today) must remember that "a city that is not on the Internet is treated as a technologically backward city" (Markowski, 2002, p. 132), and in such a city a significant part of the population simply may not want to live, study, etc., tourists may not want to visit, and potential investors - invest their capital. 


\section{References}

1. Brunk, K.H. (2010). Reputation building: beyond our control? Inferences in consumers' ethical perception formation. Journal of Consumer Behaviour, July-August, p. 278.

2. Castells, M. (1989). The Informational City. Information Technology, Economic Restructuring, and the Urban-Regional Process. Oxford, UK, Cambridge, MA: Basil Blackwell.

3. Ergazakis, K., Metaxiotis, K., and Psarras, J. (2004). Towards knowledge cities: Conceptual analysis and success stories. Journal of Knowledge Management, 8(5), pp. 5-15.

4. Florida, R.L. (2005). Cities and the Creative Class. New York, NY: Routledge.

5. Friedmann, J. (1995). Where we stand. A decade of world city research. In: P. Knox, and P. Taylor (Eds.), World Cities in a World-System (pp. 21-47). Cambridge-New York: Cambridge University Press.

6. Hollands, R.G. (2008). Will the real smart city please stand up? City, 12(3), pp. 303-320.

7. Landry, C. (2000). The Creative City: A Toolkit for Urban Innovators. London, UK: Earthscan.

8. Łebkowski, M. (2009). E-wizerunek. Internet jako narzędzie kreowania image’u w biznesie. Gliwice: Helion.

9. Mainka, A., Khveshchanka, S., and Stock, W.G. (2011.06.30). Dimensions of informational city research, in Digital Cities 7 - Real World Experiences. International Workshop at C\&T 2011, Brisbane, Australia.

10. Number of active users at Facebook over the years, Available online https://news.yahoo.com/number-active-users-facebook-over-230449748.html? guccounter=1, 14.08.2019.

11. Podlaski, A. (2011). Marketing społecznościowy. Tajniki skutecznej promocji w social media. Gliwice: Helion.

12. Rak, A. (2011). Facebook, przyjaciel czy wróg przedsiębiorstwa. Zeszyty Naukowe UE w Poznaniu, 209, p. 99.

13. Rzepecki, J., and Hankus-Matuszek, G. (2009). Wymagający użytkownik - bezcenny. Marketing $w$ praktyce, 8 , p. 36.

14. Sassen, S. (2001). The Global City. New York, London, Tokyo. Princeton, NJ: Princeton Univ. Press.

15. Shapiro, J.M. (2006). Smart cities. Quality of life, productivity, and the growth effects of human capital. Review of Economics and Statistics, 88(2), pp. 324-335.

16. Stock, W.G. (2011). Informational cities: Analysis and construction of cities in the knowledge society. Journal of the American Society for Information Science and Technology, 62(5), pp. 963-986.

17. Taylor, P.J. (2004). World City Network. A Global Urban Analysis. London: Routledge. 
18. Woźniakowski, M. (2015). Media społecznościowe w komunikacji samorządów terytorialnych. Przykład regionu świętokrzyskiego. Studia $i$ Materiały "Miscellanea Oeconomicae" (2081-2345), 4/I, pp. 291-303.

19. Yigitcanlar, T., and Han, H.J. (2010). Urban telecommunications network. Technology convergence and urban infrastructure. In: T. Yigitcanlar (Ed.), Sustainable Urban and Regional Infrastructure Development. Technologies, Applications and Management, Information Science Reference (pp. 77-90). Hershey, PA.

20. YouTube hits a billion monthly, Available online https://youtube.googleblog.com/2013/03/ onebillionstrong.html, 14.08.2019.

21. Żak, K. (2015). Media społecznościowe jako narzędzie budowania relacji przedsiębiorstwa z klientem. Zeszyty Naukowe Uniwersytetu Szczecińskiego, 117, p. 310. 